\title{
Research on Status and Improvement of Indoor Thermal Environment for Existing New Rural Building in Chengdu
}

\author{
Ling $\operatorname{Li}^{1 *}$ \\ ${ }^{1}$ Institute of Architectural Engineering, Chengdu Textile College, Chengdu, 611731, China
}

\begin{abstract}
Through the practical measurement and theoretical calculation of the indoor thermal parameters about the existing new rural building in Chengdu, this paper concludes that the indoor thermal environment of Chengdu is very poor. In addition, we propose an energy saving improvement scheme according to the "Design Standard for Energy Efficiency of Rural Residential Buildings" GB/T50824-2013 and the local characters of Chengdu. We also simulate the indoor thermal environment of existing new rural building and improved building using Design-Builder software. As compared with the existing new rural building, we know that the improved building has greatly improved in the indoor thermal environment. The indoor average temperature decreases $2{ }^{\circ} \mathrm{C}-6^{\circ} \mathrm{C}$ in summer and rises $2{ }^{\circ} \mathrm{C}-7.7^{\circ} \mathrm{C}$ in winter. As to the humidity between $30 \%$ and $60 \%$, the rise rate of each room reaches above $12.9 \%$ in summer and reaches $28.8 \%$ in winter. The rise rate of PMV index of -1 to +1 reaches above $68.4 \%$ in summer and $54.4 \%$ in winter from below $20 \%$. The improved building meets the living requirements for local resident in most time.
\end{abstract}

\section{Introduction}

After the presentation of the "three agricultural problems" on the "eleventh five-year plan" and the "twelve-five plan" have put a new socialist countryside construction as the country's major strategies. The farmer's lifestyle has been greatly changed in China because of the new building construction in rural areas. Statistics show that building energy consumption accounts for more than $30 \%$ of total energy consumption in China, even it takes up above $46.7 \%$ of total energy consumption if energy consumption in material production is taken into accounted. However, it still presents the fast growth tendency $[1,2]$. According to the National Bureau of Statistics (the People's Republic of China Bureau of Statistics, 2011), the total energy consumption of the rural building energy consumption $924.6 \mathrm{~kW} \cdot \mathrm{h}$, where commercial energy is $561.5 \mathrm{~kW} \cdot \mathrm{h}$ and biomass energy is $363.1 \mathrm{~kW} \cdot \mathrm{h}$ [3].

To a large extent, previous buildings didn't consider the technical requirements on energy efficiency. Therefore the indoor thermal environment of the existing new rural building in this area is not so good and cannot meet the human comfort requirements [4,5]. It is very important for us to study rural building energy consumption, which is study of the actual situation of energy consumption and indoor environment, as well as the characteristics of household appliances and household electrical appliances [6]. With the development of new countryside, it is significant to improve farmer's the living conditions and the indoor thermal environment by exploring the low-cost and low-tech energy saving pattern which is suitable for the new rural building.

\section{Geographical position and climate characteristics of Chengdu}

Chengdu belongs to the summer heat $\&$ winter cold zone [7] . The climate has two significant characteristics: First, it's very hot in summer, the average temperature on the hottest month can reach $25^{\circ} \mathrm{C}-30^{\circ} \mathrm{C}$. And the maximum temperature even reached above $38^{\circ} \mathrm{C}$. Air humidity is very high, and the relative humidity generally can reach $70 \%-80 \%$. In contrast the winter is cold. The lowest average temperature is $4^{\circ} \mathrm{C}$ and the lowest temperature is below $-6^{\circ} \mathrm{C}$. The typical climate of the zone is that the summer is very hot with high humidity and the winter is very clod. There is a double demand here for summer cooling and winter heating. Chengdu residents' need for the winter heating is particularly prominent.

\section{Present Situation and Problems of the Existing New rural building}

\subsection{Present forms of the existing new rural building in Chengdu}

New rural construction model in Chengdu is mainly based on the development of the regional requirements of different industries. The local government combines with the actual situation to choose unified planning and design which called "unified planning \& unified building model". Another way is that through the land exchange the farmers receive government subsidies and build the houses by

\footnotetext{
* Corresponding author: 57897864@qq.com
} 
themselves which called "unified planning \& own building model".

New countryside "unified planning \& own building model" are mostly 1-3 layer low-rise townhouses. Farmers voluntarily move into the regions. The residential flat form is free and diverse but monotonous for function zone. The first floor of the house is mainly used for leisure space, business shop, external dining room, kitchen, toilets, warehouses, etc. The second floor and the third floor is own rooms such as the bedroom, living room and so on. "unified planning \& unified building model" is mainly concentrated in the surrounding area of Chengdu. The new rural buildings are multi-layer or high-rise residential community. Community residential street have 3 surfaces facing the street and the layer are shops.

This kind of buildings have 3 types that are units one, units two and units three. New rural construction's development trend in the future is also the multi-layer and high-rise residential community inevitably. Existing new rural housing pictures are shown in Figure 1.

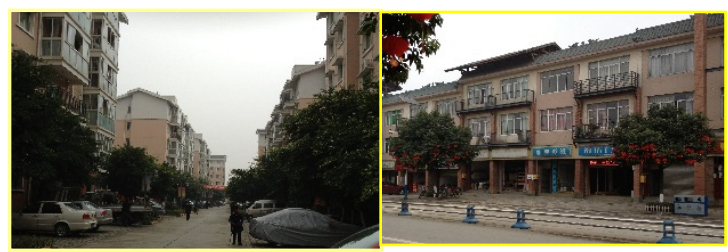

Gongxing Town's building Huangiia Town's building Fig. 1. Existing new rural building pictures

\subsection{The status of new rural residential thermal environment in Chengdu}

Although the housings are unified planned and designed and the overall style are uniform, the housing length, width, depth, size, orientation, building envelope structure failed to carry out fundamental change. Self-built new rural housings just blindly pursuit the large area and large scale. All residential construction in this mode basically has the common problem of rural housing, such as relatively large window wall, east-west gables with no measures, a hard cement surface of the roof without any heat insulation measures. Entire enclosure structure has neither winter nor summer heat insulation measures [8,9]. Thermal performance is very poor. Even the government unified plan and design, Chengdu "unified planing \& unified building model" new rural housing often only consider the area's data requirements and don't actively consider the energy-saving and low-tech pattern, not to mention the high-tech energy-saving way. The indoor thermal environment is poor.

The test data of the new rural housings shows that: In such a situation that continuous natural ventilation and no vertical exterior window shading during the summer, the indoor temperature fluctuation range is $23.2^{\circ} \mathrm{C}$ $32.3^{\circ} \mathrm{C}$.Temperature amplitude is $9.1^{\circ} \mathrm{C}$. Without any heating facilities the interior temperature fluctuation range in the winter is $4.3^{\circ} \mathrm{C}-13.2^{\circ} \mathrm{C}$. Temperature amplitude is $8.9^{\circ} \mathrm{C}$. Indoor temperature of the new rural housings in the summer is mostly in the above specification of summer indoor maximum design temperature $26^{\circ} \mathrm{C}$. The maximum temperature can reach $32.3^{\circ} \mathrm{C}$. In winter the indoor temperature throughout the day is below the interior minimum design temperature of $18^{\circ} \mathrm{C}$. Indoor thermal environment is very bad, especially in winter. Existing new rural housing test time-temperature curves are shown in Figures 2 and 3.

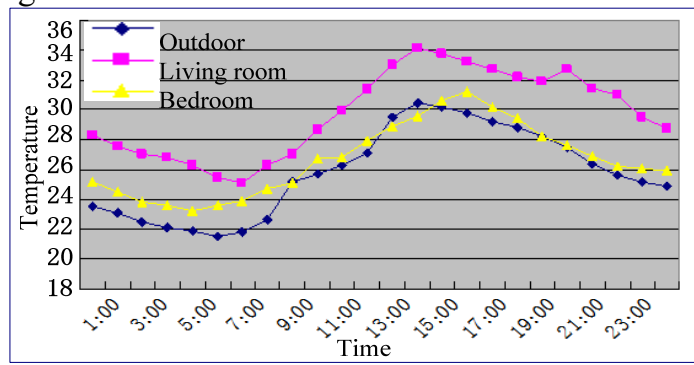

Fig.2. Time - temperature curve of summer

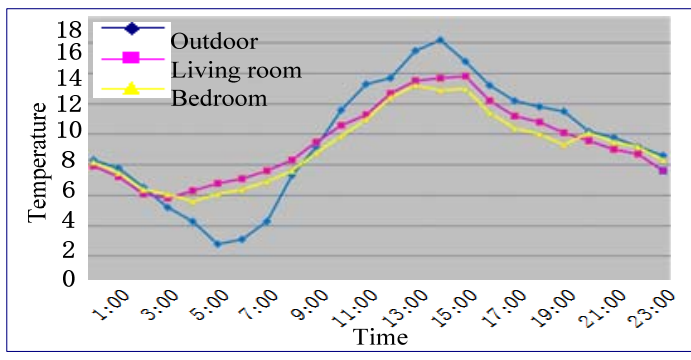

Fig.3. Time - temperature curve of winter

\section{Influencing factors and improvement measures of the indoor thermal environment of the new rural housings which have been built in Chengdu}

\subsection{The problems and improvement measures of new rural residential space form}

New rural housing construction planning, building orientation's choices and other reasons cause that the adjacent buildings shade each other, the room could not get enough solar heat, the main rooms facing the West will be exposed in the summer, indoor ventilation is not very good. Too large residential doors and windows, very poor thermal insulation properties and other reasons cause that the cooling area of peripheral maintenance structure is not enough in winter, heat loss is large and indoor temperature rises quickly due to more solar radiation in summer. It's usually cloudy, rainy and foggy in Chengdu. There is also short sunshine time and humid air. These reasons cause that indoor environment in Chengdu is cold and damp in winter and unbearably hot in summer.

Therefore, when planning the new countryside, we should take into account local climatic conditions and reasonably arrangement for the cell layout and building spacing to obtain the solar heat in winter and the best natural ventilation in summer, reducing the energy consumption in this way [10]. You can also use software such as weather tool, DOE-2 etc to assist in determining the best architectural building orientation, reasonable distance between buildings, the location and size of windows and doors. 


\subsection{The problems and improvement measures of new rural residential peripheral maintenance structure}

To solve the problem that thermal insulation performance of new rural residential peripheral maintenance structure is not so good, we combined with building energy efficiency design principles for external structure and focused on the walls, roof, structure, and windows and doors to put forward the following energy-saving design scheme for the new rural residential peripheral maintenance structure [11].

Energy-saving design of the external walls of the building $[12,13,14]$ is showed in Figure 4. The external wall base uses the $240 \mathrm{~mm}$ thick shale brick. It's thermal conductivity is $0.58 \mathrm{~W} /\left(\mathrm{m}^{2} \cdot \mathrm{K}\right)$. Wall itself has good thermal insulation effect, while the outer walls use $30 \mathrm{~mm}$ thick smear inorganic insulation mortar as the external heat preservation. The wall average heat transfer coefficient is about $1.2 \mathrm{~W} /\left(\mathrm{m}^{2} \cdot \mathrm{K}\right)$.

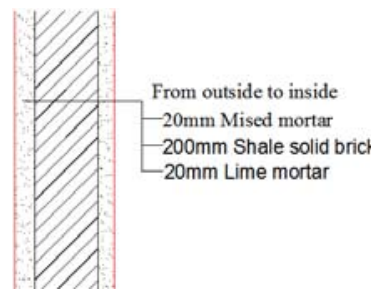

(a)

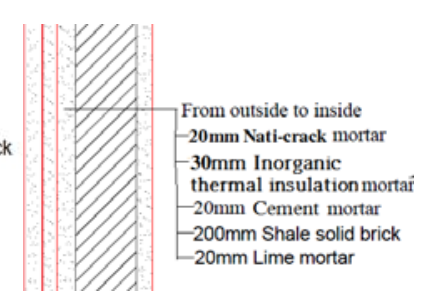

(b)
The typical residential buildings The energy-saving housings

Fig. 4. The structure of exterior walls

Energy-saving design of roof [15] is showed in Figure 5. As to the insulation material we can make full sue of the local materials such as rice husk, wood chips, straw and other crops fibber insulation materials to achieve both economic and energy-saving effect. Heat transfer coefficients of $100 \mathrm{~mm}$ thick insulation layer made of straw plate were $0.797 \mathrm{~W} /\left(\mathrm{m}^{2} \cdot \mathrm{K}\right)$, equivalent to $80 \mathrm{~mm}$ thick perlite insulation mortar $\left(\mathrm{k}=0.959 \mathrm{~W} /\left(\mathrm{m}^{2} \cdot \mathrm{K}\right)\right)$, slightly higher than $30 \mathrm{~mm}$ thick polystyrene vinyl foam plate $\left(\mathrm{k}=0.826 \mathrm{~W} /\left(\mathrm{m}^{2} \cdot \mathrm{K}\right)\right)$ and less than the energy efficiency standards of $1.0 \mathrm{~W} /\left(\mathrm{m}^{2} \cdot \mathrm{K}\right)$. Straw plate is also one kind of green building material which is biodegradable. As the raw materials of straw plate, the straw and other crop straw are the waste of crops that can be produced every year. They are usually easy to get around the town construction project and will be processed in situ. In addition to thermal insulation performance is good, the thermal insulation performance is also good and provide the strong foundation for passive solar energy design.

Energy-saving design of doors and windows [16]: According to statistics, in the case of heating or air conditioning, the heat loss of single glass windows in winter accounted for $30 \%-50 \%$ of the heat load and the cooling capacity loss in summer accounted for $20 \%-30 \%$ of air conditioning load. In Chengdu, single glass windows are widely used in the new rural housings but do not meet the standard requirements. Therefore, in the new rural construction hollow glass windows should be widely promoted. It can improve the insulation performance of windows greatly. Balcony door design is as the same as the exterior windows.

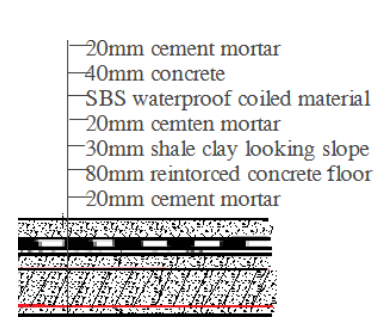

(a)

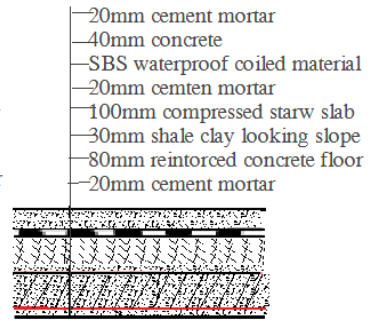

(b)
The typical residential buildings The energy-saving housings Fig. 5. The structure of exterior walls

It is promulgated the "energy efficiency design standard of rural residential building" GB / T50824-2013 in 2013. Now we compared the typical housings (A) and energy-saving housings (B) in the way of structure, heat transfer coefficients, then get the following Table 1.

Table 1. The thermal parameters analysis of typical residential buildings and the energy-saving housings

\begin{tabular}{|c|c|c|c|c|c|c|c|}
\hline \multirow[t]{2}{*}{ Building units } & \multicolumn{2}{|c|}{$\begin{array}{c}\text { Structure } \\
(\mathbf{m m})\end{array}$} & \multicolumn{2}{|c|}{$\begin{array}{c}\text { HTC } \\
\mathbf{W} /\left(m^{2} \cdot \mathbf{K}\right) \\
\end{array}$} & \multirow[t]{2}{*}{$\begin{array}{c}\text { HTCS } \\
\mathbf{W} /\left(m^{2} \cdot \mathbf{K}\right)\end{array}$} & \multicolumn{2}{|c|}{ Meet or Not } \\
\hline & A & $\mathrm{B}$ & $\mathrm{A}$ & B & & A & $\mathrm{B}$ \\
\hline exterior walls & Fig. $6 \mathrm{a}$ & $\begin{array}{c}\text { Fig. } 6 \\
\text { b }\end{array}$ & 2.13 & 1.09 & $\leq 1.5$ & No & Yes \\
\hline Roof & $\begin{array}{c}\text { Fig. } 7 \\
\text { a }\end{array}$ & $\begin{array}{l}\text { Fig. } 7 \\
\text { b }\end{array}$ & 2.67 & 0.79 & $\leq 1.0$ & $\mathrm{~N}$ & $\mathrm{Y}$ \\
\hline \multirow[b]{2}{*}{ outer doors } & $\mathrm{A}$ & SGD & \multirow{2}{*}{4.70} & \multirow[b]{2}{*}{$2.1-2.7$} & \multirow{2}{*}{$\leq 3.0$} & \multirow{2}{*}{$\mathrm{N}$} & \multirow[b]{2}{*}{$\mathrm{Y}$} \\
\hline & $\mathrm{B}$ & PVC-PHGD & & & & & \\
\hline \multirow{2}{*}{ outer windows } & $\mathrm{A}$ & SGW & \multirow{2}{*}{4.70} & \multirow{2}{*}{$2.1-2.7$} & \multirow{2}{*}{$\leq 3.2$} & \multirow{2}{*}{$\mathrm{N}$} & \multirow{2}{*}{$\mathrm{Y}$} \\
\hline & B & PVC- PHGW & & & & & \\
\hline
\end{tabular}

HTC:Heat transfer coefficient

HTCS:Heat transfer coefficient in the Standard SGD:single glass- steel door

PVC-PHGD: PVC plastic hollow glass door

SGW:Single glass-steel window

PVC-PHGW: PVC plastic hollow glass window 
4.3 The problems and improvement measures of summer cooling and winter heating of new rural housings in Chengdu

The indoor environment in Chengdu is cold and wet in winter, unbearably hot in summer. In the survey, the usage rate of air conditioning is more than $50 \%$ in winter and summer. As the way of heating in winter air conditioning is high energy consumption and low comfort. So it is not suitable for winter heating.

Therefore, it can give priority to warm heating or radiators in the winter. The floor heating mainly depends on the radiant heating. The loss of radiant heating is very small and comfort degree is very high. Air conditioning makes the use of the air cycle to heat the air by electricity. The heat load per square meter is very large so that the cost of electricity is higher. In summer we can use the split inverter air conditioner which can improve the cooling effect by starting in advance and changing the air supply angle. And the split air-conditioning installation is more convenient. The one-time investment is not high. It is also more convenient to use and flexible to control the use of each space.

\section{Simulation and comparative analysis of indoor thermal environment of new rural housings in Chengdu}

\subsection{The model creation of the typical new rural housings in Chengdu}

The new rural residential housing model in Chengdu is seen in Figure 6. Design-Builder simulation model. Figure 7 is a planar graph of a typical rural residence.

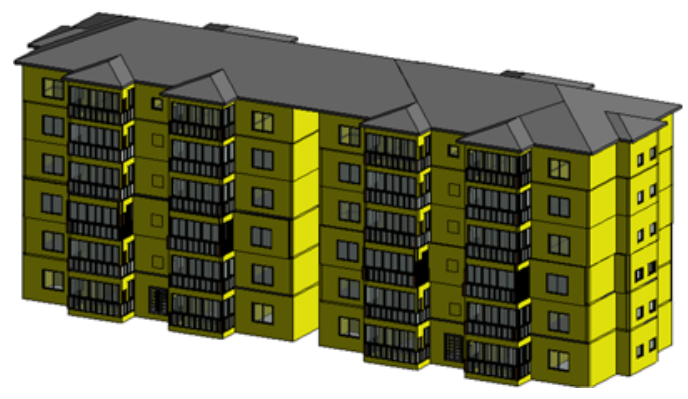

Fig.6. Design-Builder simulation model

\subsection{The indoor thermal environment simulation of the typical new rural housings which has been built in Chengdu and energy-saving housings}

Based on the meteorological data of Chengdu in the "standard meteorological database of chinese building", we can use the typical meteorological data of winter and summer to calculate the indoor thermal environment parameter. The simulation parameters of typical new rural housings and energy-saving housings are seen in Table 1. In Design-Builder simulation, illumination area is 1001x and the air exchange rate is $1 / \mathrm{h}$ in winter. The thermal resistance of clothing is $1,83 \mathrm{clo}$ in winter and $0.26 \mathrm{clo}$ in summer.

In summer there is $80 \%$ or above of time that the indoor temperature is above $30^{\circ} \mathrm{C}$ and $30 \%$ of time that the indoor temperature is above $35^{\circ} \mathrm{C}$ in typical new rural housings. In this environment the body feels uncomfortable. In winter there is only $20 \%$ of time that the indoor temperature is above $14^{\circ} \mathrm{C}$ and partial time that the indoor temperature is below $8^{\circ} \mathrm{C}$ that is intolerant. As to the indoor relative humidity, it mostly meets the requirement in summer but the half time can not meets the requirement in winter. The time that the PMV index of each room is $-1 \sim+1$ is mostly below $20 \%$. So the thermal environment of the typical new rural housing in the climate condition of Chengdu is very poor and cannot meet the living requirements.

The indoor thermal environment of the energy-saving housings improved greatly. In summer the indoor temperature is always below $30^{\circ} \mathrm{C}$ that is the uncomfortable temperature of body. There is above $70 \%$ of time is below the $28^{\circ} \mathrm{C}$ which is the comfortable temperature. In winter the indoor temperature can reach $14^{\circ} \mathrm{C}$ in most time and is always above $8^{\circ} \mathrm{C}$. No matter in summer or winter the relative humidity of each room can meet the requirements. And the time that the PMV index of each room is $-1 \sim+1$ is mostly above $70 \%$. So the thermal environment of the energy-saving housings Chengdu is very good and can meet the living requirements in most time.

\subsection{Simulation and comparative analysis of indoor thermal environment of new rural housings in Chengdu}

Compared with the typical new rural housings, the energysaving housings improved greatly in the way of indoor thermal environment of major room. The situation of improvement is as Table 2 .

In Table 2, we can see that the indoor thermal environment parameter of energy-saving housings improved a lot. The indoor temperature in summer decreases $2^{\circ} \mathrm{C}-6^{\circ} \mathrm{C}$ and rises $2^{\circ} \mathrm{C}-7.7^{\circ} \mathrm{C}$ in winter. As to the humidity, the rise rate of each room in summer reach above $12.9 \%$ and reach $28.8 \%$ in winter. The rise rate of PMV index of $-1 \sim+1$ reach above $68.4 \%$ in summer and $54.4 \%$ in winter from below $20 \%$. This shows that the energy-saving design of peripheral maintenance structure is the important measure to improve the indoor thermal environment.

Table 2 Improvement of indoor thermal environment of energy-saving housings

\begin{tabular}{|c|c|c|c|c|c|c|c|}
\hline \multirow{2}{*}{$\mathrm{MP}$} & \multirow{2}{*}{ room } & \multirow{2}{*}{$\triangle \mathrm{Teq}^{\circ} \mathrm{C}$} & $\leq 35^{\circ} \mathrm{C}$ & \multirow{2}{*}{$\leq 28^{\circ} \mathrm{C}$} & \multirow{2}{*}{$\begin{array}{c}\triangle \mathrm{PH} \\
\%\end{array}$} & $\begin{array}{c}\text { HUM } 30- \\
60 \%\end{array}$ & $\begin{array}{c}\text { PMV index } \\
-1-1\end{array}$ \\
& & \multicolumn{2}{|c|}{$\mathrm{IN} \%$} & \multicolumn{3}{|c|}{$\mathrm{IN} \%$} \\
\end{tabular}




\begin{tabular}{|c|c|c|c|c|c|c|c|}
\hline \multirow{4}{*}{ Sum. } & MB & -4.6 & 32.3 & 81.8 & -27.2 & 12.9 & 82.5 \\
\hline & BR1 & -5.7 & 30.7 & 84.1 & -9.5 & 18.9 & 80.2 \\
\hline & BR2 & -6.0 & 28.2 & 74.5 & -11.0 & 12.9 & 74.8 \\
\hline & LR & -2.0 & 42.1 & 63.8 & -19.8 & 18.7 & 68.4 \\
\hline \multirow{6}{*}{ Win. } & \multirow[t]{2}{*}{ room } & \multirow[t]{2}{*}{$\begin{array}{c}\triangle \mathrm{Teq} \\
{ }^{\circ} \mathrm{C}\end{array}$} & $\geq 8$ & $\geq 18$ & \multirow[t]{2}{*}{$\begin{array}{l}\triangle \mathrm{PH} \\
{ }^{\circ} \mathrm{C}\end{array}$} & $\begin{array}{c}\text { HUM } 30- \\
60 \%\end{array}$ & $\begin{array}{c}\text { PMV index -1- } \\
1\end{array}$ \\
\hline & & & \multicolumn{2}{|c|}{ IN \% } & & \multicolumn{2}{|c|}{ IN\% } \\
\hline & MB & 7.7 & 20.4 & 81.0 & -29.6 & 30.4 & 76.1 \\
\hline & BR1 & 5.5 & 18.8 & 75.2 & -29.0 & 28.8 & 75.7 \\
\hline & BR2 & 2.0 & 29.5 & 70.5 & -22.0 & 40.3 & 55.0 \\
\hline & LR & 5.3 & 71.6 & 57.5 & -17.5 & 38.8 & 54.5 \\
\hline
\end{tabular}

MP:meteorological parameters

IN:increase the numbers

\section{Conclusions}

Through the field tests of indoor and outdoor temperature of Chengdu typical new rural housings in summer and winter, the analysis of peripheral maintenance structure of typical new rural housings and the theory calculation of heat transfer coefficients, we can get the conclusion that the indoor thermal

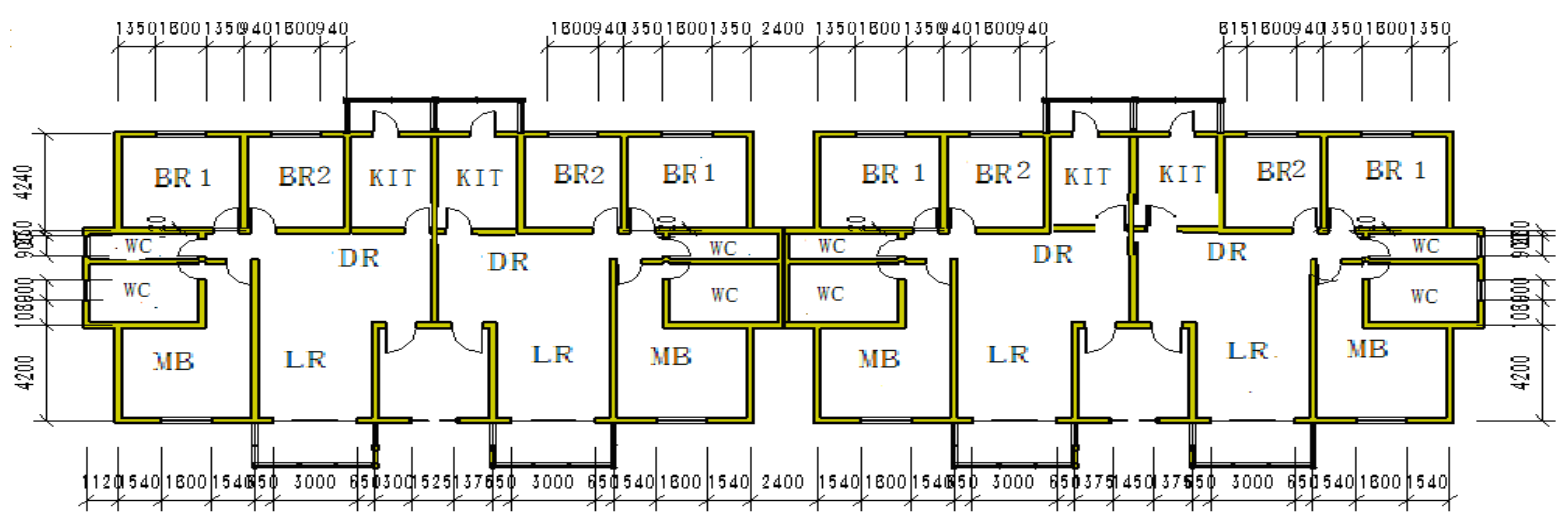

Fig.7. The planar graph of a typical rural residence

environment of typical new rural housings in this region is very poor and cannot meet the living requirements.

Combined with the characteristics of Chengdu region this paper put forward the energy-saving housings design. Through the analysis of peripheral maintenance structure and the theory calculation of heat transfer coefficients of energy-saving housings, we get the conclusion that the energy-saving housings can meet the requirements of energy-saving design standard.

Finally, through the Design-Builder simulation of typical new rural housings and energy-saving housings, we analyze the indoor thermal environment parameters: indoor average temperature, tolerate indoor temperature, indoor average humidity, the humidity proportion of $30 \% \sim 60 \%$, PMV parameter $-1 \sim+1$. Its analysis and comparison shows that no matter in summer or winter the indoor thermal parameter of energy-saving housings improved a lot. It improves the indoor comfort and meets the living requirements in most time.

\section{Acknowledgement}

This work is supported by the Natural Science Project of Sichuan Education Department (Grant No. 16ZB0371)

\section{References}

1. W.G. Cai, Y. Wu, Y. Zhong, and H. Ren, China building energy consumption: Situation, challenges and corresponding measures. Energy Policy, 37 (6):2054-2059(2009).

2. Lu Shilei,Tang Xiaolei,Ji Liran,et al.Research on Energy-Saving Optimization for the Perfomance Parameters of Rural-Building Shape and Envelope by TRNSYS-GenOpt in Hot Summer and Cold Winter Zone of China[J].MDPI,9(2):1-18(2017)

3. National Bureau of Statistics of People's Republic of China.China statistical.(2011).

4. Ministry of Housing and Urban-Rural Development (MOHURD), \& National Standard, GB (GB/T 50824-2013). (2013). Design standard for energy efficiency of rural residential buildings. Beijing: Chinese Statistics Press.

5. M. Shan, P.S. Wang, \& J.R. Li, Energy and environment in Chinese rural buildings: Situations, challenges, and intervention strategies. Building and Environment, 96(1)271-282(2015).

6. T.C. Hua, H. Yoshino, Z.T. Jiang, Analysis on urban residential energy consumption of Hot Summer \& Cold Winter Zone in China. Sustainable Cities and 
Society, 6:85-91(2013).

7. X.J. Gao, The life cycle routes for the green residential buildings in China's low-carbon city background. Advanced Materials Research, 347:1387-1390(2011)

8. May Zune,Lucelia Rodrigues Mark Gillott. Vernacular passiv design in Myanmar housing for thermal comfort [J].Sustainable Cities and society, $54: 101992(2020)$.

9. S. Niu, X. Zhang, C. Zhao, Y. Ding, Y. Niu, and T.H. Christensen, Household energy use and emission reduction effects of energy conversion in Lanzhou city, China. Renewable Energy.36(5)1431-1436 (2011) .

10. Y. Jiang, C. Peng, D. Yan, China's building energy roadmap[J]. Construction Science and Technology.17: 12-19(2012).

11. W. Xu, S. Luo, C. Xu, and J. Li, Referential building determination method for evaluation of rural building energy saving in Beijing $[\mathrm{J}]$. Architecture Technology.41 (5)403-405(2010).

12. F. Lv, C. Cao, and R.F. Su, Concerning the application of grass brick house in rural construction-make Shangdianzi Village in Jilin Province as an example. Advanced Materials Research. 450:1456-1460(2012).

13. F. Barreca,C.R. Fichera.Wall panels of Arundo donax L. for environmentally sustainable agriculture buildings:Thermal performance evaluation[J]. Journal of Food Agriculture \& Environment.11 (2) 1353-1357(2013).

14. Angélica Walsh,Daniel Cóstola.Comparison of three climatic zoning methodologies for building energy efficiency applications[J].Energy \&Buildings, 13871390(2017)

15. Angélica Walsh,Daniel Cóstola, Lucila C. Labaki.Comparison of three climatic zoning methodologies for building energy efficiency applications[J].Energy \& Buildings . 2017

16. H.L. Ma, J.F. Wang, \& M. Ji, Cold regions of the roof on the building energy consumption impact, in: International Conference on Advanced Research on Advanced Structure, Materials and Engineering (ASME 2011), Beijing, China, pp. 215-219. 